\title{
GNRH2 Gene Product
}

National Cancer Institute

\section{Source}

National Cancer Institute. GNRH2 Gene Product. NCI Thesaurus. Code C136787.

A protein encoded by the GNRH2 gene. 